\title{
ANALISIS PSIKOLOGIS KOMPARATIF PENDEKATAN PEMBELAJARAN KI HADJAR DEWANTARA DAN BENJAMIN S. BLOOM
}

\author{
Idrus L. \\ idrus.latif@yahoo.co.id \\ Program Doktor UIN Alauddin Makassar
}

\begin{abstract}
Ki Hadjar Dewantara and Benjamin S. Bloom have different learning approach in term of psychological aspect in learning activities. Ki Hajar Dewantara tends to maximize the potency of each individual i.e., (educate the head, the heart, and the hand) and the social-cultural totality in interacting with the environment with "sistem among: care and dedication based on love. In another hand, Benjamin S. Bloom emphasizes on behaviorism theory which believes that learning is an internal process includes memory, retention, information process, energy and other psychological aspects. From the character learning, Ki Hajar Dewantara focuses on attitude of students, how they communicate, humanism, and the physical aspect of student. It integrates the art and cultural aspect in learning process while Benjamin S. Bloom streghtening the cognitive aspect of student by implementing behaviorism learning process.
\end{abstract}

Keywords: Learning approach, Ki Hajar Dewantara, Benjamin S. Bloom

Diterima: 16-07-2019, Direview: 25-07-2019, Diterbitkan: 15-08-2019

\section{PENDAHULUAN}

Diakui atau tidak bahwa karakter generasi muda akhir-akhir ini banyak mengalami kelunturan akhlak yang sangat dahsyat. Generasi muda sekarang, baik di desa maupun di kota banyak menghabiskan waktunya hanya untuk bermain playstation, berselancar dimedia sosial, game online dan sejenisnya, mereka mulai melupakan pentingnya interaksi sosial dan akan nilai-nilai budaya lokal serta asing terhadap istilah-istilah seperti budi pekerti, tata krama, gotong royong dan nilai-nilai luhur lainnya.

Anak dalam kesehariannya jika disuguhi dengan kesibukan yang tidak jelas, permainan yang melalaikan, serta berbagai tontonan yang tidak berkualitas, maka dapat dipastikan ia akan cenderung prilakunya menjadi kurang sopan, ramah dan jauh dari kata 
berakhlak mulia. Hal ini tentu akan merugikan terhadap dirinya sendiri juga lingkungan sekitarnya.

Achmadi (2009: 31) mengutip pernyataan Azyumardi Azra bahwa munculnya kembali gagasan pendidikan budi pekerti gagasan tokoh Ki Hadjar Dewantara harus diakui berkaitan erat dengan semakin berkembangnya pandangan dalam masyarakat luas dan pengaruh globalisasi, bahwa pendidikan nasional dalam berbagai jenjangnya, khususnya jenjang menengah dan tinggi dianggap telah gagal membentuk kepribadian peserta didik yang berakhlak mulia, bermoral dan budi pekerti yang baik. Lebih jauh lagi, dijumpai banyak peserta didik sering dinilai tidak hanya kurang dalam kesantunan, baik di sekolah, rumah dan lingkungan masyarakat, tetapi juga sering terlihat dalam tindak kekerasan massal seperti tawuran dan lainnya.

Penulis beranggapan bahwa kemerosotan akhlak, moral dan etika peserta didik disebabkan gagalnya pendidikan agama di sekolah. Harus diakui, dalam batas tertentu, pendidikan agama memiliki kelemahan-kelemahan tertentu mulai dari jumlah jam yang minim, materi pendidikan agama yang terlalu banyak teoritis sampai kepada pendekatan pendidikan agama yang cenderung bertumpu pada aspek kognisi dari pada afeksi dan psikomotorik peserta didik (Yaumi, 2014: 41). Berhadapan dengan berbagai kendala, constraints, dan masalah-masalah seperti ini, pendidikan agama tidak atau kurang fungsional dalam membentuk akhlak, moral, dan bahkan kepribadian peserta didik.

Berkenan dengan krisis mentalitas dan moral peserta didik, terdapat beberapa masalah pokok yang turut menjadi akar krisis mentalitas dan moral di lingkungan pendidikan nasional (Nata, 2005: 127) yakni (1) arah pendidikan telah kehilangan objektivitasnya. Sekolah dan lingkungannya tidak lagi merupakan tempat peserta didik melatih diri untuk berbuat sesuatu berdasarkan nilai-nilai moral dan akhlak, (2) proses pendewasaaan diri tidak berlangsung baik di lingkungan sekolah, (3) proses pendidikan disekolah sangat membelenggu peserta didik dan bahkan juga para guru, (4) beban kurikulum yang demikian berat, lebih parah lagi, hampir seluruhnya diorientasikan pada pengembangan ranah kognitif belaka, (5) kalaupun ada materi yang dapat menumbuhkan rasa afeksi seperti mata pelajaran agama misalnya, umumnya disampaikan dalam bentuk verbalisme, (6) pada saat yang sama para peserta didik dihadapkan dengan nilai-nilai yang sering bertentangan (contra-dictory set of values). Pada satu pihak mereka diajar para guru pendidikan agamanya untuk bertingkah laku baik, seperti: jujur, hemat, rajin, disiplin dan sebagainya, tetapi pada saat yang sama, banyak orang di lingkungan sekolah justru 
melakukan tindakan berlawanan dengan hal-hal seperti itu. (7) selain itu para peserta didik juga mengalami kesulitan dalam mencari figur panutan untuk dijadikan sebagai teladan (uswah hasanah) di lingkungan sekolah maupun di lingkungan masyarakat.

Masalah yang disebut di atas, hampir dapat dipastikan hanyalah merupakan tip of iceberg dari krisis yang dihadapi pendidikan nasional umumnya. Krisis yang dihadapi kelihatannya bukan hanya menyangkut kinerja sekolah atau dunia pendidikan umumnya dalam hal kualitas akademis lulusannya, melainkan dalam hal mentalitas, moral dan karakter sehingga tidak ragu lagi, keberhasilan dalam mendidik dan membentuk akhlak, moral dan budi pekerti atau karakter peserta didik pada tingkat dasar dan menengah merupakan langkah paling fundamental dalam membentuk karakter bangsa.

Pendidikan humanis semestinya dibumikan kembali yang menjadi konsep utama pemikiran Ki Hadjar Dewantara, konsep yang lebih menekankan pentingnya pelestarian eksistensi manusia, dalam arti membantu manusia lebih manusiawi, lebih berbudaya, berbudi pekerti sebagai manusia yang utuh berkembang, menurut Ki Hadjar Dewantara yang perlu dikembangkan menyangkut daya cipta (kognitif), daya rasa (afektif), dan daya karsa (konatif). (Achmad dan Widodo, 2004: 39) Pengembangan manusia seutuhnya menuntut pengembangan semua daya secara seimbang, pengembangan yang terlalu menitikberatkan pada satu daya saja akan menghasilkan ketidakutuhan perkembangan sebagai manusia. Ki Hadjar Dewantara mengatakan bahwa pendidikan yang menekankan pada aspek intelektual belaka hanya akan menjauhkan peserta didik dari masyarakatnya. Dan ternyata pendidikan sampai sekarang ini hanya menekankan pada pengembangan daya cipta dan kurang memperhatikan pengembangan olah rasa dan karsa. Jika berlanjut terus akan menjadikan manusia kurang humanis atau manusiawi.

Hanya saja konsep Ki Hadjar Dewantara dengan teori pendidikan budi pekertinya hanya sebuah teori pendidikan dan belum diterapkan di Indonesia secara utuh. Kiblat pendidikan di Indonesia masih mengacu pada produk barat karya Benjamin S. Bloom dengan teori taksonominya. Taksonomi Bloom telah mempengaruhi pendidikan baik secara langsung maupun tidak langsung dalam pengembangan kurikulum, desain pembelajaran dan pendidikan guru di Indonesia.

Teori taksonomi Bloom populer dengan tiga ranahnya, yakni (1) ranah kognitif, yang mencakup ingatan atau pengenalan terhadap fakta-fakta tertentu, pola-pola prosedural dan konsep-konsep yang memungkinkan berkembangnya kemampuan dan skill intelektual (Huda, 2013: 169). (2) ranah afektif, ranah yang berkaitan perkembangan perasaan, sikap, 
nilai dan emosi; (3) ranah psikomotor, ranah yang berkaitan dengan kegiatan-kegiatan manipulatif atau keterampilan motorik (Degeng, 2013: 202) lebih populer dibanding teori pendidikan Ki Hadjar Dewantara.

Dari uraian atas timbul pemikiran untuk mengkaji secara analisis psikologis komparatif pendekatan pembelajaran Ki Hadjar Dewantara dan Benjamin S. Bloom perbandingan pendekatannya yakni konsep pendekatan pembelajarannya dan perlakuannya kepada peserta didik dengan membandingkan dua konsep pemikiran Ki Hadjar Dewantara dan Benjamin S. Bloom.

\section{A. Pendekatan Pembelajaran Ki Hadjar Dewantara dan Benjamin S. Bloom di kelas 1. Pendekatan Pembelajaran Ki Hadjar Dewantara}

Konsep dasar pendidikan Ki Hajar Dewantara dikenal dengan tiga slogan, yakni:

a. Ing ngarsa sung tulada, berarti guru sebagai pendidik berdiri di depan dan harus mampu memberi teladan kepada anak didiknya. Guru harus bisa menjaga tingkah lakunya supaya bisa menjadi teladan (Soeratman, 1985: 27).

b. Ing madya mangun karsa, berarti seorang pendidik ketika berada di tengah harus mampu membangkitkan semangat, berswakarsa dan berkreasi pada anak didik (Idris, 1983: 15).

c. Tut wuri handayani, berarti seorang pendidik berada di belakang, mengikuti dan mengarahkan anak didik agar berani berjalan di depan dan sanggup bertanggung jawab (Soeratman, 1985: 27).

Penerapan slogan tersebut, digunakan metode among dengan semboyan Tut Wuri Handayani. Metode among berarti membimbing anak dengan penuh kecintaan dan mendahulukan kepentingan sang anak. Anak berkembang menurut kodratnya. Dengan dasar kekeluargaan dalam metode among hubungan antara murid dan guru sangat erat. Sifat keluarga mengandung unsur-unsur: 1) cinta mencintai sesama anggota keluarga, 2) sesama hak dan sesama kewajiban, 3) tidak ada nafsu menguntungkan diri dengan merugikan anggota lain, 4) kesejahteraan bersama, dan 5) sikap toleran (Fudyarta,--: 81).

Dalam memberi pelajaran, supaya tidak membosankan dan menyenangkan, contoh-contoh yang digunakan dari kehidupan sehari-hari yang dikenal murid (Soeratman, 1985: 83). Dengan demikian, pelajaran yang diberikan menjadi gamblang (jelas) dan dapat meresap pada ingatan anak didik. 
Sifat, sistem, dan metode pendidikan menurut Ki Hadjar Dewantara diringkas ke dalam empat kemasan, yaitu asas Taman Siswa, Panca Darma, adat istiadat, dan semboyan atau perlambang (Yaumi, 2014: 31).

Menurut Ki Hadjar Dewantara, adab dan keluhuran budi manusia menunjukkan sifat batin manusia, misal kesadaran tentang kesucian, kemerdekaan keadilan, keTuhanan, cinta kasih, kesetiaan, kesenian, ketertiban, kedamaian, kesosialan dan sebagainya, sedangkan kesusilaan atau kehalusan menunjukkan sifat hidup lahir manusia yang serba halus dan indah. Sering dipakai kata etis dan estetis, yang menunjukkan sifat manusia yang luhur dan halus/indah itu (Soeratman, 1985: 27).

Dengan demikian, mengimplementasikan ajaran Ki Hajar Dewantara dalam pembelajaran dengan sistem among yang berpusat pada siswa dengan memperhatikan situasi, kondisi, sikap dan perilaku siswa, agar kerjasama kelompok dapat berjalan dengan baik sehingga dapat terlihat kerja siswa perseorangan dan interaksi siswa dalam kelompok.

\section{Pendekatan Pembelajaran Benjamin S. Bloom}

Taksonomi didefinisikan sebagai kerangka landasan atau sebuah klasifikasi. Di dalam pedagogia Bloom, pembelajaran dibagi menjadi tiga area, yakni (1) bidang kognitif; (2) bidang afektif dan (3) bidang psikomotor (Sukarjo dan Ukim, 2009: 8).

Keberadaan taksonomi ini merupakan landasan dalam penyusunan konsep pendidikan, baik kurikulum maupun proses pembelajaran dan pengajaran. Setiap proses pembelajaran yang akan dilaksanakan setidaknya harus mengacu pada tiga aspek yang ditawarkan oleh taksonomi Bloom ini, karena dengan mengacu pada tiga aspek atau ranah ini, secara tidak langsung memberikan gambaran tentang beberapa hal yang harus di perhatikan oleh pendidik di setiap berlangsungnya program pembelajaran. Pada tingkatan yang lebih praktis, taksonomi ini telah banyak membantu para praktisi pendidikan untuk menformulasikan tujuan-tujuan belajar dalam bahasa yang mudah di pahami, rasional, serta dapat diukur (Sukarjo dan Ukim, 2009: 8). Dengan demikian, penerapan pembelajaran akan lebih efektif dan mampu mencapai tujuan dari pembelajaran yang didambakan, sebagaimana pokok dari konsep taksonomi ini yang menekankan pada tujuan pendidikan.

Taksonomi Bloom dalam ranah kognitif mengklasifikasikan perilaku menjadi enam kategori, dari yang sederhana (mengetahui) sampai dengan yang lebih kompleks (mengevaluasi) yakni (1) pengetahuan $(\mathrm{C} 1)$; (2) pemahaman $(\mathrm{C} 2)$; (3) penerapan $(\mathrm{C} 3)$; (4) analisis (C4); (5) sintesis (C5); (6) evaluasi (C6). 
Taksonomi Bloom ranah kognitif berturut-turut dari yang paling sederhana sampai yang paling kompleks diilustrasikan seperti pada gambar berikut:

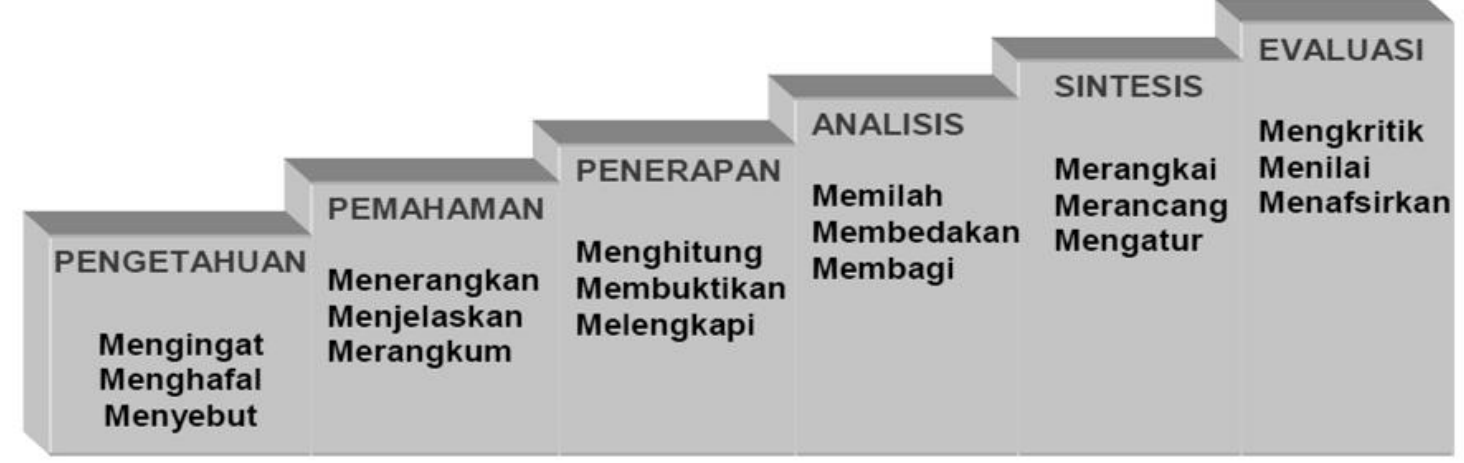

Gambar 1. Taksonomi Bloom ranah kognitif

Perkembangan berikutnya, taksonomi Bloom direvisi oleh muridnya Lorin W. Anderson dan David R. Krathwohl. Perubahannya ada titik dimensi proses kognitif dalam taksonomi revisi terbagi menjadi 6 kategori yaitu: mengingat, memahami, mengaplikasikan, menganalisis, mengevaluasi, dan mencipta. Kategori-kategori tersebut akan dijelaskan dalam Tabel 1 berikut:

Tabel 1. Kata Kerja Operasional (KKO) Revisi Taksonomi Bloom (ANDERSON, L.W. dan Krathwohl, D.R.: 2001)

\section{a) Ranah Kognitif}

\begin{tabular}{|c|c|c|c|c|c|c|c|c|c|}
\hline $\begin{array}{l}\text { Taksonomi } \\
\text { Bloom Lama }\end{array}$ & $\begin{array}{c}\text { C1 } \\
\text { (Pengetahuan) }\end{array}$ & $\begin{array}{c}\text { C2 } \\
\text { (Pemahaman) }\end{array}$ & & $\begin{array}{l}\text { C3 } \\
\text { plikasi) }\end{array}$ & & $\begin{array}{l}\text { C4 } \\
\text { nalisis) }\end{array}$ & \multicolumn{2}{|c|}{$\begin{array}{c}\text { C5 } \\
\text { (Sintesis) }\end{array}$} & $\begin{array}{c}\text { C6 } \\
\text { (Evaluasi) }\end{array}$ \\
\hline $\begin{array}{l}\text { Taksonomi } \\
\text { Bloom Revisi }\end{array}$ & $\begin{array}{c}\mathrm{C} 1 \\
\text { (Mengingat) }\end{array}$ & $\begin{array}{c}\mathrm{C} 2 \\
\text { (Memahami) }\end{array}$ & (Me & $\begin{array}{l}\text { C3 } \\
\text { aplikasikan) }\end{array}$ & & $\begin{array}{l}\text { C4 } \\
\text { ganalisis) }\end{array}$ & \multicolumn{2}{|c|}{$\begin{array}{c}\text { C5 } \\
\text { (Mengevaluasi) }\end{array}$} & $\begin{array}{c}\text { C6 } \\
\text { (Mencipta) }\end{array}$ \\
\hline $\begin{array}{l}\text { Mengingat } \\
\text { (remember) }\end{array}$ & $\begin{array}{l}\text { Memahami } \\
\text { (Understad) }\end{array}$ & \multicolumn{2}{|c|}{$\begin{array}{c}\text { Mengaplikasikan } \\
\text { Apply) }\end{array}$} & \multicolumn{2}{|c|}{$\begin{array}{l}\text { Menganalisis } \\
\text { (Analyze) }\end{array}$} & \multicolumn{2}{|c|}{$\begin{array}{l}\text { Mengevaluasi } \\
\text { (Evaluate) }\end{array}$} & \multicolumn{2}{|c|}{$\begin{array}{l}\text { Mencipta } \\
\text { (Create) }\end{array}$} \\
\hline Mengutip & Memperkirakan & \multicolumn{2}{|l|}{ Mengaskan } & \multicolumn{2}{|c|}{ Memecahkan } & \multicolumn{2}{|c|}{ Membandingkan } & \multicolumn{2}{|c|}{ Mengumpulkan } \\
\hline Menebitkan & Menceritajan & \multicolumn{2}{|l|}{ Menentukan } & \multicolumn{2}{|c|}{ Menegaskan } & \multicolumn{2}{|c|}{ Menilai } & \multicolumn{2}{|c|}{ Mengatur } \\
\hline Menjelaskan & Merinci & \multicolumn{2}{|l|}{ Menerapkan } & \multicolumn{2}{|c|}{ Meganalisis } & \multicolumn{2}{|c|}{ Mengarahkan } & \multicolumn{2}{|c|}{ Erancang } \\
\hline Memasagkan & Megubah & \multicolumn{2}{|l|}{ Memodifikasi } & \multicolumn{2}{|c|}{ Menimpulkan } & \multicolumn{2}{|l|}{ Mengukur } & \multicolumn{2}{|c|}{ Membuat } \\
\hline Membaca & Memperluas & \multicolumn{2}{|l|}{ Membangun } & \multicolumn{2}{|c|}{ Menjelajah } & \multicolumn{2}{|c|}{ Meangkum } & \multicolumn{2}{|c|}{ Merearasi } \\
\hline Menamai & Menjabarkan & \multicolumn{2}{|l|}{ Mencegah } & \multicolumn{2}{|l|}{ Mengaitkan } & \multicolumn{2}{|c|}{ Mendukung } & \multicolumn{2}{|c|}{ Memperjelas } \\
\hline Meninjau & Mnconthkan & \multicolumn{2}{|l|}{ Melatih } & \multicolumn{2}{|l|}{ Mentransfer } & \multicolumn{2}{|l|}{ Memilih } & Mengara & \\
\hline Mentabulasi & Mengemukakan & Menyelidiki & & Mengedit & & Memproye & sikan & Menyusu & \\
\hline Memberi kode & Menggali & Memproses & & Menemukan & & Mengkritil & & Mengode & \\
\hline Menulis & Mengubah & Memecahkan & & Menyeleksi & & Mengarah & & Mengkor & binasikan \\
\hline Menytakan & Menghitung & Melakukan & & Mengoreksi & & Memutuka & & Memfasi & itasi \\
\hline Menunjukkan & Menguraikan & Mensimulasik & & Mendeteksi & & Memisahk & & Mengkor & struksi \\
\hline Mendaftar & Mempertahankan & Mengurutkan & & Menelaah & & menimban & & Merumu & kan \\
\hline Menggambar & Mngartikan & Membiasakan & & Mengukur & & & & Menghul & ungkan \\
\hline Membilang & Menerangkan & Mengklasifik: & & Membangur & & & & Mencipta & kan \\
\hline Mengidentifikasi & Menafsirkan & Menyesuaikar & & Merasionalk & & & & Menamp & lkan \\
\hline Menghafal & Memprediksi & Menjalankan & & Mendiagnos & & & & & \\
\hline Mencatat & Melaporkan & Mengoperasik & & Memfokusk & & & & & \\
\hline Meniru & membedakan & Meramalkan & & Memadukan & & & & & \\
\hline
\end{tabular}




\section{b.) Ranah Afektif}

\begin{tabular}{|c|c|c|c|c|}
\hline $\begin{array}{c}\text { A1 } \\
\text { Menerima }\end{array}$ & $\begin{array}{c}\text { A2 } \\
\text { Merspon }\end{array}$ & $\begin{array}{c}\text { A3 } \\
\text { Menghargai }\end{array}$ & $\begin{array}{c}\text { A4 } \\
\text { Mengorganisaikan }\end{array}$ & $\begin{array}{c}\text { A5 } \\
\text { Karakterisasi } \\
\text { Menurut Nilai }\end{array}$ \\
\hline $\begin{array}{l}\text { Mengikuti } \\
\text { Menganut } \\
\text { Mematuhi } \\
\text { Meminati }\end{array}$ & $\begin{array}{l}\text { Menyenangi } \\
\text { Menyambut } \\
\text { Mendukung } \\
\text { Maporkan } \\
\text { Memilih } \\
\text { Menampilkan } \\
\text { Menyetujui } \\
\text { Mengatakan }\end{array}$ & $\begin{array}{l}\text { Mengsumsikan } \\
\text { Meyakinkan } \\
\text { Memperjelas } \\
\text { Menekankan } \\
\text { Menyumbang } \\
\text { Mengimani }\end{array}$ & $\begin{array}{l}\text { Mengubah } \\
\text { Menata } \\
\text { Membangun } \\
\text { Membentuk pendapat } \\
\text { Memadukan } \\
\text { Mengelola } \\
\text { Merembuk } \\
\text { Menegoisasi }\end{array}$ & $\begin{array}{l}\text { Membiasakan } \\
\text { Mengubah perilaku } \\
\text { Berakhlak mulia } \\
\text { Melayani } \\
\text { Membuktikan } \\
\text { Memecahkan }\end{array}$ \\
\hline
\end{tabular}

\section{c.) Ranah Psikomotorik}

\begin{tabular}{|c|c|c|c|c|}
\hline $\begin{array}{c}\text { P1 } \\
\text { Meniru }\end{array}$ & $\begin{array}{c}\text { P2 } \\
\text { Manipulasi }\end{array}$ & $\begin{array}{c}\text { P3 } \\
\text { Presisi }\end{array}$ & $\begin{array}{c}\text { P4 } \\
\text { Artikulasi }\end{array}$ & $\begin{array}{c}\text { P5 } \\
\text { Naturalisasi }\end{array}$ \\
\hline $\begin{array}{l}\text { Menyalin } \\
\text { Mengikuti } \\
\text { Mereplikasi } \\
\text { Mengulangi } \\
\text { Mematuhi } \\
\text { Mengaktifkan } \\
\text { Menyesuaikan } \\
\text { Menggabungkan } \\
\text { Melamar } \\
\text { Mengatur } \\
\text { Mengumpulkan } \\
\text { Menimbang } \\
\text { Memperkecil } \\
\text { Membangun } \\
\text { Mengubah } \\
\text { Membersihkan } \\
\text { Memposisikan } \\
\text { Mengkonstruksi }\end{array}$ & $\begin{array}{l}\text { Kembali membuat } \\
\text { Membangun } \\
\text { Melakukan } \\
\text { Melaksanakan } \\
\text { Menerapkan } \\
\text { Mengoreksi } \\
\text { Mendemonstrasikan } \\
\text { Merancang } \\
\text { Memilah } \\
\text { Melatih } \\
\text { Memperbaiki } \\
\text { Mengidentifikasikan } \\
\text { Mengisi } \\
\text { Menempatkan } \\
\text { Membuat } \\
\text { Memanipulasi } \\
\text { Mereparasi } \\
\text { Mencampur }\end{array}$ & $\begin{array}{l}\text { Menunjukkan } \\
\text { Melengapi } \\
\text { Menyempurnakan } \\
\text { Mengkalibrasi } \\
\text { Mengendalikan } \\
\text { Mengalihkan } \\
\text { Menggantikan } \\
\text { Memutar } \\
\text { Mengirim } \\
\text { Memindahkan } \\
\text { Mendorong } \\
\text { Menarik } \\
\text { Memproduksi } \\
\text { Mencampur } \\
\text { Mengoperasikan } \\
\text { Mengemas } \\
\text { Membungkus }\end{array}$ & $\begin{array}{l}\text { Membangun } \\
\text { Mengatasi } \\
\text { Menggabungkan } \\
\text { Beradaptasi } \\
\text { Memodifikasi } \\
\text { Merumuskan } \\
\text { Mengalihkan } \\
\text { Mempertajam } \\
\text { Membentuk } \\
\text { Memadankan } \\
\text { Menggunakan } \\
\text { Memulai } \\
\text { Menyetir } \\
\text { Menjelaskan } \\
\text { Menempel } \\
\text { Menskestsa } \\
\text { Mendengarkan } \\
\text { Menimbang }\end{array}$ & $\begin{array}{l}\text { Mendesain } \\
\text { Menentukan } \\
\text { Mengelola }\end{array}$ \\
\hline
\end{tabular}

Berdasarkan hasil analisis di atas, pendekatan pembelajaran Benjamin S. Bloom lebih kepada model belajar kognitif dengan menggabungkan teacher centered approach dan student centered approach. Analisis penulis melihat bahwa konsep pembelajaran yang berkembang terfokus pada proses- proses aktif, kognitif dan konstruktif dalam pembelajaran yang bermakna. Pembelajar diasumsikan sebagai pelaku yang aktif dalam aktivitas belajar; mereka memilih informasi yang akan mereka pelajari, dan mengonstruksi makna berdasarkan informasi. Pembelajaran kognitif yang menekankan siswa untuk mengetahui (pengetahuan) dan bagaimana mereka berpikir (proses kognitif) tentang yang mereka ketahui ketika aktif dalam pembelajaran. Dimensi proses kognitif berisikan enam kategori yaitu: mengingat, memahami, mengaplikasikan, menganalisis, mengevaluasi, dan mencipta. 
Dimensi pengetahuan berisikan empat kategori yaitu faktual, konseptual, prosedural, dan metakognitif.

\section{B. Analisis Psikologis Komparatif Pendekatan Pembelajaran Ki Hadjar dan Bloom Terhadap Siswa}

\section{Pendekatan Pembelajaran secara psikologis Ki Hadjar Dewantara}

Sistem pendidikan dan pengajaran Ki Hajar Dewantara mempunyai nilai-nilai filosofis yang mendalam. Hal ini dapat dilihat secara jelas pada pandangan-pandangannya tentang pendidikan. Salah satu di antaranya adalah idenya untuk memonitor dan berkomunikasi dengan siswa didiknya yang dijalankan dengan menganut prinsip-prinsip sistem among.

Model pendekatan pembelajaran Ki Hadjar Dewantara yang diimplementasikan di Taman Siswa didirikannya pada tanggal 3 Juli 1922 (Hariyadi, 1989: 109)., yaitu: 1) Sistem kelasnya kelas inklusif, dimana siswa yang pintar dan kurang pintar dijadikan satu; 2) Pelajaran ilmu hitung tidak diperkenalkan pada pendidikan dasar; 3) Tidak ada ujian sekolah pada tingkat pendidikan dasar; 4) Tidak ada rangking untuk anak didik; 5) Anak usia dini pembentukan karakter lebih diutamakan; 6) Jam pelajaran hanya 2-4 jam sehari, waktu istirahat mencapai 75 menit, jarang ada PR, dan 7) Satu kelas diisi maksimal 15 orang murid (Degeng, 1998: 2)

Kurikulum sekolah dirancang untuk memberikan pembelajaran kepada peserta didik agar dapat menunjukkan jati dirinya masing- masing (Soeratman, 1984: 17). Kurikulum tersebut di antaranya yaitu: 1) isi kurikulum atau rencana pelajaran bersifat kultural nasional; 2) segala pelajaran harus dapat membangkitkan perasaan cinta kepada tanah air dan bangsa; 3) di samping pendidikan kecerdasan, dipentingkan juga penjagaan dan latihan kesusilaan, serta pendidikan kebudayaan yang bersifat kebangsaan; 4) bahasa Indonesia sebagai bahasa persatuan dan bahasa pengantar diwajibkan, dan bahasa daerah yang penting diajarkan secukupnya dalam daerahnya masing-masing, adapun bahasa asing diberikan untuk keperluan melanjutkan pelajaran dan menambah perhubungan dengan luar negeri.

Model pendidikan yang diimplementasikan Ki Hadjar Dewantara melalui Taman Siswa tersebut juga identik dengan model Tri Pusat Pendidikan, yang meliputi: alam keluarga, alam perguruan, dan alam pemuda. Dimana, ketiga hal tersebut merupakan pusat pendidikan yang membantu menuju kecerdasan jiwa maupun budi pekerti. 
Dengan demikian, pendekatan pembelajaran Ki Hadjar Dewantara secara psikologis lebih kepada proses pembentukan karakter didasarkan pada totalitas psikologis yang mencakup seluruh potensi individu manusia (olah pikir, olah hati, olah raga, dan olah rasa/karsa) dan totalitas sosial-kultural dalam berinteraksi di lingkungan masyarakat.

\section{Pendekatan Pembelajaran secara psikologis Benjamin S. Bloom}

Secara umum pendekatan pembelajaran Benjamin S. Bloom tidak secara spesifik disebutkan dalam berbagai literatur, tetapi hanya menyebutkan secara garis besar pendekatan pembelajaran dalam pendidikan. Pemikiran Benjamin S. Bloom dalam dunia pendidikan lebih umum dibandingkan pemikiran Ki Hadjar Dewantara (Yaumi: 2014: 47). Namun, pendekatan pembelajaran secara psikologis Benjamin S. Bloom lebih kepada model belajar kognitif (Degeng, 1998: 63).

Adapun pendekatan pembelajaran pendidikan yang umum digunakan, yakni:

a. Pendekatan Expository

Pendekatan ini menekankan pada penyampaian informasi yang disampaikan sumber belajar kepada murid untuk menuntaskan materi (Degeng, 1998: 223). sehingga dalam pembelajaran cenderung berpusat pada sumber belajar dengan memiliki ciri-ciri, yaitu: (1) adanya dominasi sumber belajar dalam pembelajaran, (2) bahan belajar terdiri atas konsep-konsep dasar atau materi yang baru bagi warga belajar, (3) materi lebih cenderung bersifat informasi, (4) terbatasnya sarana pembelajaran (Degeng, 1998: 224).

\section{b. Pendekatan Inquiry}

Pendekatan inquiry ditujukan kepada cara belajar yang menggunakan cara penelaahan atau pencarian terhadap sesuatu objek secara kritis dan analitis sehingga dapat membentuk pengalaman belajar yang bermakna. Dalam kegiatan pembelajaran, sumber belajar menyajikan bahan tidak sampai tuntas, tetapi memberi peluang kepada warga belajar untuk mencari dan menemukannya sendiri dengan menggunakan berbagai cara pendekatan masalah. Jadi, peran sumber belajar adalah sebagai pembimbing/fasilitator yang dapat mengarahkan warga belajar dalam kegiatan pembelajarannya secara efektif dan efisien.

Berdasarkan hasil analisis di atas, dinyatakan bahwa pendekatan pembelajaran secara psikologis Benjamin S. Bloom lebih kepada model belajar kognitif yang berpandangan bahwa belajar merupakan suatu proses internal yang mencakup ingatan, retensi, pengolahan informasi, energi, dan aspek-aspek kejiwaan lainnya. 
Pendekatan dijalankan dengan menganut prinsip-prinsip teori kognitif, yakni gambaran perseptual, organisasi pengetahuan, belajar dengan pemahaman, umpan balik, penetapan tujuan, dan berpikir devergen.

\section{Relevansi Pendekatan Pembelajaran Ki Hadjar dan Bloom Terhadap Pengembangan Karakter}

Pendidikan berkarakter dalam istilah sederhananya adalah pendidikan Budi pekerti berasal dari kata budi yang diartikan sebagai jiwa yang sudah masak (Dewantara, 1962: 2627). Demikian pula menurut Koentjaraningrat (1985: 191) bahwa budi berarti akal, sedang pekerti adalah perbuatan, tingkah laku, tindakan yang dilakukan oleh manusia. Berdasarkan hal tersebut budi pekerti dapat ditafsirkan sebagai tingkah laku manusia atas dasar akal atau pemikiran dari jiwa yang masak.

Kata budi pekerti erat sekali berhubungan dengan budaya karena keduanya samasama berkaitan dengan akal dan tindakan yang dilakukan oleh manusia dalam hidup bermasyarakat. Budi pekerti adalah bagian dari kebudayaan yang mengajarkan tentang kesopanan, moral, tingkah laku dan keluhuran budi yang harus dilakukan oleh seseorang.

Menurut ajaran Ki Hadjar Dewantara (1962: 27) bahwa seseorang yang berwatak adalah yang memiliki disiplin diri. memiliki sopan santun. Demikian pula dipandang dari sudut konsep Benjamin S. Bloom adalah perilaku bahwa pemahaman siswa tentang disiplin diri tidak ada dan rasa rendah hati juga tidak ada sehingga yang muncul secara afektif adalah perilaku tidak menghargai waktu yang akhirnya berdampak meremehkan orang lain yaitu pengajar atau guru (Syarkawi, 2014: 24).

Dalam rangka lebih memperkuat pelaksanaan pendidikan karakter di Indonesia telah teridentifikasi 18 nilai yang bersumber dari agama, Pancasila, budaya dan tujuan Pendidikan Nasional yaitu: religius, jujur, toleransi, disiplin, kerja keras, kreatif, mandiri, demokratis, rasa ingin tahu, semangat kebangsaan, cinta tanah air, menghargai prestasi, bersahabat/komunikatif, cinta damai, gemar membaca, peduli lingkungan, peduli sosial, dan tanggung jawab (Kemdiknas, 2010: 8).

Terkait dengan relevansi pendekatan pembelajaran Ki Hadjar dan Bloom terhadap 18 nilai-nilai pendidikan karakter di Indonesia internalisasinya dapat dilakukan melalui tiga jalur, yaitu (1) integrasi melalui mata pelajaran, (2) integrasi melalui muatan lokal dan (3) integrasi melalui pengembangan diri. 
Berkaitan dengan hal di atas, relevansi pendekatan pembelajaran Ki Hadjar adalah daya upaya untuk memajukan budi pekerti, pikiran, serta jasmani anak, agar dapat memajukan kesempurnaan hidup, yaitu hidup dan menghidupkan anak yang selaras dengan alam dan masyarakatnya. Selain itu, meningkatkan pengetahuan anak didik tentang apa yang dipelajari, mengasah rasa untuk meningkatkan pemahaman, serta meningkatkan kemampuan untuk melaksanakan yang dipelajarinya (Samanni dan Hariyanto, 2011: 35).

Pelaksanaan pendidikan melalui sistem among yang diperkenalkan oleh Ki Hadjar lebih diarahkan pada anak didik, dalam istilah disebut student center. Dalam sistem ini pelaksanaan pendidikan lebih didasarkan pada minat dan potensi yang perlu dikembangkan pada anak didik, bukan pada minat dan kemampuan pengajar. Dengan demikian, pengajar hanya memotivasi perkembangan kemampuan siswa saja agar dapat mencapai tujuan tersebut Taman siswa menyelenggarakan kerjasama yang seimbang antara sekolah, keluarga dan masyarakat (Samanni dan Hariyanto, 2011: 35).

Relevansi pendekatan pembelajaran Benjamin S. Bloom terhadap pengembangan karakter lebih fokus pada aspek kognitif saja yang terdiri atas: 1) ranah kognitif, yaitu seorang pengajar benar-benar menguasai ilmu pengetahuan yang akan diajarkan dan diberikan pada siswanya, logika berpikir guru sangat dituntut sebaik mungkin karena hal itu akan berpengaruh pada sistim pengajarannya misalnya dalam memilah-milah materi pelajaran, merumuskan materi secara singkat dan padat sehingga siswa akan lebih mudah memahami; 2) ranah afektif, yakni siswa memahami dan merespon pelajaran yang diterima siswa, sehingga seorang pengajar harus pandai pandai memotivasi siswa agar tertarik untuk memahami apa yang diajarkan; dan 3) ranah psikomotorik, yakni seorang pengajar harus pandai pandai memberikan pengetahuan pada siswa untuk diketahui kemudian dipahami secara benar secara signifikan sehingga yang diketahuinya dapat dapat dilaksanakan dan dipraktikan secara benar sesuai maksud pengajar. Potensi potensi yang dimiliki oleh para siswa pun akan kelihatan dengan menghasilkan berbagai hasil kreativitas.

Adapun strategi penerapan pendekatan pembelajaran Ki Hadjar dan Bloom kaitannya dengan pendidikan karakter di Indonesia, yakni:

1. Kegiatan pembelajaran

Dalam rangka mengembangkan karakter peserta didik, kegiatan pembelajaran difokuskan pada pendekatan student centered sebagai konsep belajar dan mengajar yang membantu guru dan peserta didik mengaitkan antara materi yang diajarkan dengan 
situasi dunia nyata sehingga peserta didik mampu untuk membuat hubungan antara pengetahuan yang dimilikinya dengan penerapannya dalam kehidupan mereka.

2. Pengembangan Budaya Sekolah dan Pusat Kegiatan Belajar

Pengembangan budaya sekolah dan pusat kegiatan belajar dilakukan melalui kegiatan pengembangan diri, berupa: kegiatan rutin, kegiatan spontan, keteladanan, dan pengkondisian.

3. Kegiatan ko-kurikuler dan atau kegiatan ekstrakurikuler

Pelaksanaan kegiatan ko-kurikuler atau kegiatan ekstrakurikuler perlu didukung dengan dengan perangkat pedoman pelaksanaan, pengembangan kapasitas sumber daya manusia dalam rangka mendukung pelaksanaan pendidikan karakter, dan revitalisasi kegiatan ko dan ekstrakurikuler yang sudah ada ke arah pengembangan karakter.

4. Kegiatan keseharian di rumah dan di masyarakat

Sekolah mengupayakan terciptanya keselarasan antara karakter yang dikembangkan di sekolah dengan pembiasaan di rumah dan masyarakat.

\section{KESIMPULAN}

Berdasarkan hasil analisis dan pembahasan dapat disimpulkan sebagai berikut:

1. Pendekatan Pembelajaran Ki Hadjar Dewantara di kelas lebih berorientasi pada siswa (student centered approach), sedangkan Benjamin S. Bloom lebih kepada model belajar kognitif dengan menggabungkan teacher centered approach dan student centered approach.

2. Pendekatan pembelajaran Ki Hadjar Dewantara secara psikologis lebih kepada proses pembentukan karakter didasarkan pada totalitas psikologis yang mencakup seluruh potensi individu manusia (olah pikir, olah hati, olah raga, dan olah rasa/karsa) dan totalitas sosial-kultural dalam berinteraksi di lingkungan masyarakat dengan menganut prinsip sistem among, sedangkan Benjamin S. Bloom lebih kepada model belajar kognitif yang berpandangan bahwa belajar merupakan suatu proses internal yang mencakup ingatan, retensi, pengolahan informasi, energi, dan aspek-aspek kejiwaan lainnya dengan menganut prinsip-prinsip teori kognitif, yakni gambaran perseptual, organisasi pengetahuan, belajar dengan pemahaman, umpan balik kognitif, penetapan tujuan, dan berpikir devergen. 
3. Pendekatan pembelajaran Ki Hadjar Dewantara dan Benjamin S. Bloom memiliki kesamaan terhadap pengembangan karakter. Relevansi pendekatan pembelajaran Ki Hadjar Dewantara adalah memajukan budi pekerti, pikiran, jasmani siswa, serta meningkatkan pengetahuan siswa tentang yang dipelajari, mengasah rasa untuk meningkatkan pemahaman, serta meningkatkan kemampuan untuk melaksanakan yang dipelajarinya. Sistem pelaksanaan pendidikan lebih didasarkan pada minat dan potensi siswa sehingga guru hanya memotivasi perkembangan kemampuan siswa tersebut, sedangkan relevansi pendekatan pembelajaran Benjamin S. Bloom terhadap pengembangan karakter lebih fokus pada aspek kognitif saja yang terdiri atas ranah kognitif (logika berpikir guru sangat dituntut agar materi yang diberikan mudah dipahami siswa), ranah afektif (guru harus pandai memotivasi agar siswa tertarik untuk memahami yang diajarkan), dan ranah psikomotorik (guru harus pandai memberikan pengetahuan pada siswa untuk diketahui, kemudian dipahami secara benar secara signifikan sehingga dapat dilaksanakan dan dipraktikkan oleh siswa secara benar sesuai maksud guru/pengajar).

\section{DAFTAR PUSTAKA}

Achmadi. (2009). Ideologi Pendidikan Islam. Yogyakarta: Pustaka Pelajar.

Ahmadi, Abu \& Widodo. (2004). Psikologi Belajar. Jakarta: PT. Rineka Cipta.

Alsa, A. (2003). Pendekatan Kuantitatif dan Kualitatif, serta Kombinasinya dalam Penelitian Psikologi. Yogyakarta: Pustaka Pelajar.

Degeng, I.N.S. (2013). Ilmu Pembelajaran: Klasifikasi Variabel untuk Pengembangan Teori dan Penelitian. Bandung: Kalam Hidup.

(1998). Makalah disajikan dalam Pidato Pengukuhan Guru Besar IKIP Malang: Mencari Paradigma Baru Pemecahan Masalah Belajar dari Keteraturan Menuju Kesemrawutan Malang: INS.

Dewantara, K. H. (1962). Karja I (Pendidikan). Yogjakarta: Pertjetakan Taman Siswa.

Fudyarta, K. (----). Tinjauan Filosofis Terhadap Pendidikan Sistem Among. Yogyakarta: Majelis Luhur Persatuan Taman Siswa.

Hariyadi, K. (1989). Ki Hadjar Dewantara sebagai Pendidik, Budayawan, Pemimpin Rakyat dalam Buku Ki Hadjar Dewantara dalam Pandangan Para Cantrik dan Mentriknya. Yogyakarta: MLTS.

Huda, M. (2013). Model-model Pengajaran dan Pembelajaran. Yogyakarta: Pustaka Pelajar.

Idris, Z. (1983). Dasar-Dasar Kependidikan. Bandung: Angkas. 
Kemdiknas. (2010). Desain Induk Pendidikan Karakter. Jakarta: Kemediknas.

Koentjoroningrat. (1985). Pengantar Antropologi. Jakarta: Akasara Baru.

Nata, A. (----). Tokoh-tokoh Pembaruan Pendidikan Islam di Indonesia. Jakarta: PT.

Samani, M. \& Hariyanto. (2011). Konsep dan Model Pendidikan Karakter. Bandung:: Rosda.

Soeratman, D. (1984). Ki Hajar Dewantara. Jakarta: Depdikbud.

Soeratman, P. (1985). Ki Hajar Dewantara. akarta, Departemen Pendidikan dan Kebudayaan, Proyek Pembinaan Pendidikan Dasar.

Sukarjo, M. \& Ukim K. (2009). Landasan Pendidikan (Teori dan Aplikasinya). Jakarta: Rajawali Press.

Suryabrata, S. (2010). Metodologi Penelitian. Jakarta: Rajagrafindo Persada.

Syarkawi. (2011). Pembentukan Kepribadian Anak: Peran Moral, Intelektual, Emosional, dan Sosial Sebagai Wujud Integrasi Jati Diri. Jakarta: Bumi Aksara.

Warsono. (2011). Bunga Rampai Pendidikan Karakter Strategi Mendidik Generasi Masa Depan: Pendidikan Budaya dan Karakter Bangsa di Sekolah Dasar. Surabaya: Unesa Universty Press.

Yaumi, M. (2014). Pendidikan Karakter (Landasan, Pilar dan Implementasi). Jakarta: Prenada Media. 